\title{
Everyday Exposure to Occupational/Non-Occupational Infrasound Noise in Our Life
}

\author{
Adam ZAGUBIEŃ, Katarzyna WOLNIEWICZ \\ Faculty of Civil Engineering, Environmental and Geodetic Science \\ Koszalin University of Technology \\ Śniadeckich 2, 75-453 Koszalin, Poland; e-mail: adam.zagubien@tu.koszalin.pl
}

(received April 6, 2016; accepted June 10, 2016)

\begin{abstract}
Infrasounds are very common in the natural environment. There are various opinions about their harmfulness or lack of harmfulness. One of the reasons of increasing interest in this issue is that there are more and more wind farms appearing close to building estates which are undoubtedly a source of infrasound. It is reasonable to present the results of research of infrasound noise connected not only with wind farms. In this study own results of research of infrasound noise related to daily human activity are presented. The measurements were carried out during housework, travel to the office or shop, and during shopping. The results are shown in the form of values of equivalent levels and $1 / 3$-octave analyses. Taking into consideration the natural sources of infrasound in the environment, the measurements were conducted during both windy and windless weather. On the basis of the results of the measurements it was possible to define the daily exposure to infrasound noise. Those results were also compared with the available in the literature threshold values sensed by people. Estimated level of exposure to noise beyond workplace together with the level of exposure to noise at work enables to define daily exposure level, which means a better assessment of risk of health loss. Increasing social awareness of acoustic threat in everyday life allows us to identify the problem and at the same time improve the quality of rest and efficiency at work.
\end{abstract}

Keywords: infrasound; non-occupational noise exposure; noise levels.

\section{Introduction}

The basic aspect concerning the right assessment of human exposure to noise is dividing the issue into two parts: occupational and non-occupational human activity. Estimated level of exposure to non-occupational noise together with exposure to noise at workplace or work environment would enable to estimate the total daily exposure level.

This fact can have an essential meaning during assessing the impact of infrasound noise. Especially it concerns people who are equally or more exposed to noise in a non-occupational environment than at workplace. Increasing people's awareness of acoustic threats in everyday human life helps to identify the problem and at the same time helps to improve the quality of rest and work efficiency. "This fact does not allow us to neglect the duty to monitor the dangers - we learn to take the responsibility for the natural environment all life!" (Piecuch, Piecuch, 2011).
In this article, the definition of infrasound noise is taken according to the Polish norm (PN-Z-01338, 2010) and norm ISO (ISO 7196, 1995). Infrasound noise is the noise of spectra of frequency from 1 to $20 \mathrm{~Hz}$. Infrasound is connected with all types of human activity, not only at workplace but also in the social environment. The sources of infrasound can be of natural and anthropogenic origin. Natural sources are for example: sea waves, waterfalls, or earthquakes. Main sources of infrasound of anthropogenic origin are: means of transport, industrial machines, compressors, ventilators, or air-conditioning (PAWLAS et al., 2013). Infrasound noise is sensed by humans either by hearing and beyond-hearing way - by vibration receptors placed all over the body. The authors (BERGLUnd, Hassemen, 1996; Leventhall et al., 2003; PawlaCZYK-ŁUSZCZYŃSKA, 1999) highlight that arduous impact of infrasound noise is characterised by symptoms such as exhaustion, discomfort, sleeplessness, impaired balance, psychomotor skills, and disruption 
Table 1. Average values of audible threshold [dB].

\begin{tabular}{|l|c|c|c|c|c|c|c|c|}
\hline \multirow{2}{*}{ Author } & \multicolumn{7}{|c|}{ Frequency $[\mathrm{Hz}]$} \\
\cline { 2 - 9 } & 1 & 2 & 4 & 8 & 10 & 12.5 & 16 & 20 \\
\hline MøLLER, PEDERSEn, 2004 & 122 & 115 & 108 & 98 & 92 & 89 & 82 & 74 \\
\hline WATANBE, MøLLER, 1990 & & & 108 & 100 & 97 & 92 & 88 & 79 \\
\hline VAN DER BERG, 2005 & & & 119 & & 103 & & & 85 \\
\hline
\end{tabular}

of physiological functions. Changes in the central nervous system are an objective proof of these symptoms. The infrasound is usually not perceived as a tonal sound but rather as a pulsating sensation, pressure on the ears or chest. The most bothersome impact of infrasound is very often connected with the situation when acoustic pressure level exceeds the perception threshold. Audible perception thresholds have not been normalised so far. Average values of the threshold of hearing infrasound are presented below on the basis of literature data (VAN DER BERG, 2005; MøLLER, Pedersen, 2004; Watanabe, Møller, 1990).

The assessment of measurement results was carried out according to the document (JACOBSEN, 2001), including Dutch guidelines concerning permissible infrasound levels in rooms from outside sources. These guidelines describe the level of $85 \mathrm{dBG}$ as maximum level suggested in most rooms. Unfortunately in Poland there are not any regulations describing permissible levels of infrasound noise both at workplace and natural environment. The only standard covering this issue in Poland is the norm (PN-Z-01338, 2010) describing the measurement method and assessment of infrasound noise at workplace. This norm includes also the reference levels which are the burden criteria of value $102 \mathrm{dBG}$ for eight-hour or one-week exposure and $86 \mathrm{dBG}$ at workplace requiring special concentration.

\section{Methodology}

The measurements were made by a digital analyser and by the meter of sound and vibration level SVAN 912AE class 1 . The set was equipped with the analyser, sound registering device and microphonic pre-amplifier SVA, microphone SV02/C4L, a windscreen, and acoustic calibrator. The characteristics of the microphone in the range of low frequencies is shown in Fig. 1. The whole equipment had valid calibration certificate. The measurement track was calibrated before and after the measurements. The analysis was carried out in $1 / 3$ octave spectra in the range of $1 \mathrm{~Hz}-16 \mathrm{kHz}$ without correction. Then the results were digitally corrected by the filter G correction according to the norm (ISO 7196, 1995). The time of a single measurement was the same as the time of the task and activity (specific times are presented in Tables 2 and 3 - last column). Each measurement was conducted at least 3 times and the chosen results presented in this work are closest to the average value of all 3 measurements. During the measurement the microphone was set at the height of person's ear who was performing the daily activities

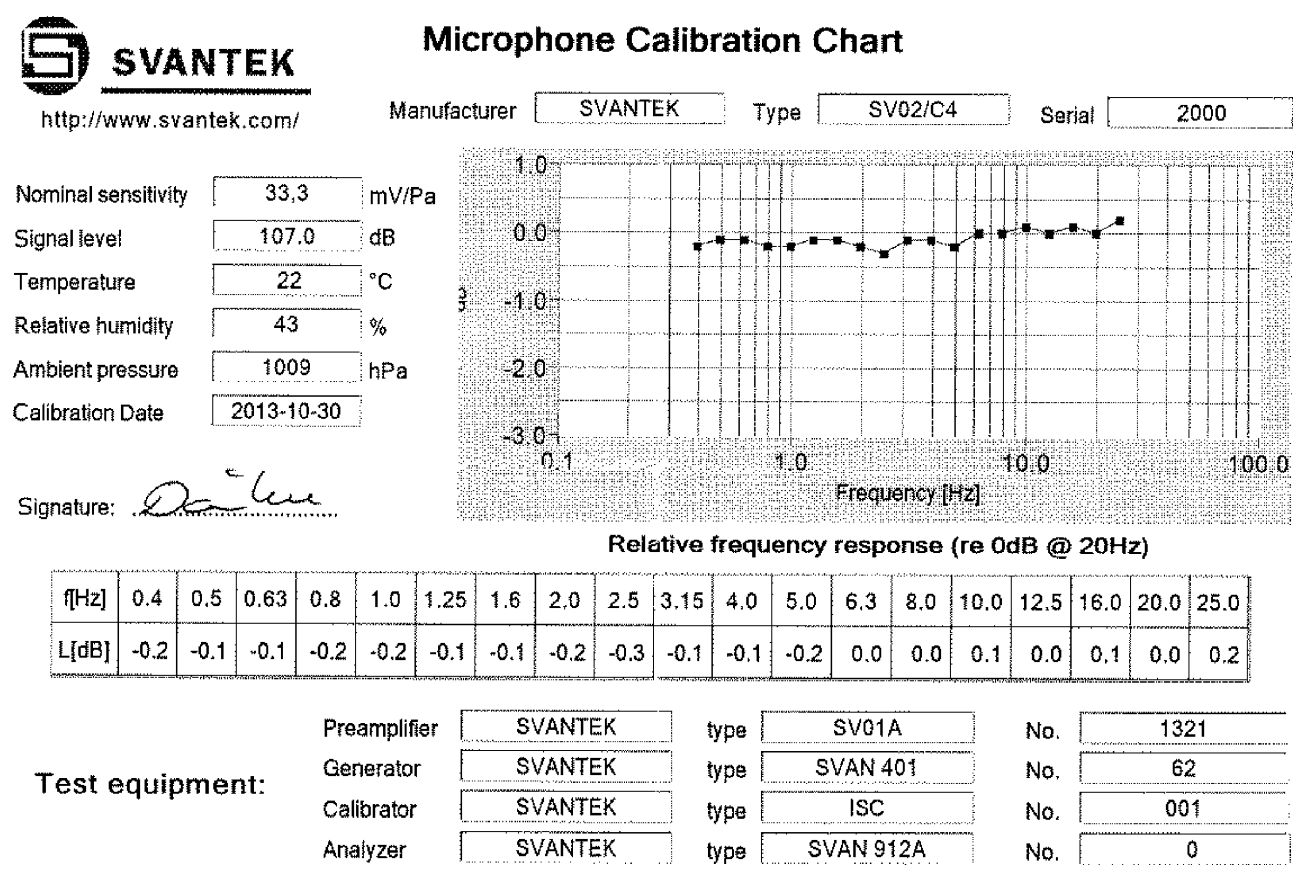

Fig. 1. Microphone characteristics within the range of low frequencies of sound pressure. 
Table 2. Schedule of activities of a housewife.

\begin{tabular}{|c|c|c|c|c|}
\hline $\begin{array}{l}\text { Activity } \\
\text { No. }\end{array}$ & $\begin{array}{c}\text { No. of measurement } \\
\text { analysis } \\
\text { (with wind/without wind) }\end{array}$ & Name of activity & Devices in motion & $\begin{array}{l}\text { Length } \\
\text { of activity } \\
\text { [min] }\end{array}$ \\
\hline 1 & A59/A69 & $\begin{array}{l}\text { Everyday hygiene, } \\
\text { taking a shower }\end{array}$ & $\begin{array}{l}\text { Shower, toilet flushing, washing } \\
\text { machine, fridge in the distance }\end{array}$ & 25 \\
\hline 2 & $\mathrm{~A} 58 / \mathrm{A} 70$ & Laundry washing & $\begin{array}{l}\text { Washing machine, running wa- } \\
\text { ter, fridge in the distance }\end{array}$ & 25 \\
\hline 3 & $\mathrm{~A} 50 / \mathrm{A} 64$ & Preparing meals & $\begin{array}{l}\text { Electric kettle, fridge, dish- } \\
\text { washer }\end{array}$ & 90 \\
\hline 4 & A51/A66 & Cooking dinner & $\begin{array}{l}\text { Mechanical ventilation over the } \\
\text { electric cooker, fridge }\end{array}$ & 75 \\
\hline 5 & $\mathrm{~A} 44 / \mathrm{A} 68$ & Hobby & $\begin{array}{l}\text { Heating stove with a closed } \\
\text { combustion chamber in the } \\
\text { room, fridge in the distance }\end{array}$ & 90 \\
\hline 6 & $\mathrm{~A} 43 / \mathrm{A} 24$ & $\begin{array}{l}\text { Rest, menial home activ- } \\
\text { ities, reading press and } \\
\text { web sides surfing }\end{array}$ & $\begin{array}{l}\text { Fridge and heating stove in the } \\
\text { distance, computer }\end{array}$ & 180 \\
\hline 7 & $\mathrm{~A} 42 / \mathrm{A} 82$ & $\begin{array}{l}\text { Walk, collecting children } \\
\text { from school }\end{array}$ & Traffic noise & 90 \\
\hline 8 & $\mathrm{~A} 21 / \mathrm{A} 22$ & $\begin{array}{l}\text { Going to the shop by lo- } \\
\text { cal means of transport }\end{array}$ & Bus - combustion engine & 60 \\
\hline $8^{*}$ & A26/A36 & Going to the shop by car & Car - combustion engine & 60 \\
\hline 9 & $\mathrm{~A} 84 / \mathrm{A} 23$ & Grocer's shopping & $\begin{array}{l}\text { Shop devices, fridges, and freez- } \\
\text { ers }\end{array}$ & 60 \\
\hline 10 & A53/A71 & Vacuuming & $\begin{array}{l}\text { Vacuum cleaner, fridge in the } \\
\text { distance }\end{array}$ & 25 \\
\hline 11 & $\mathrm{~A} 60 / \mathrm{A} 20$ & Watching TV & TV set, fridge in the distance & 180 \\
\hline 12 & $\mathrm{~A} 5 / \mathrm{A} 25$ & Sleeping & $\begin{array}{l}\text { Fridge and heating stove in the } \\
\text { distance }\end{array}$ & 540 \\
\hline
\end{tabular}

Table 3. Schedule of home activities of a person working outside home.

\begin{tabular}{|c|c|l|l|c|}
\hline $\begin{array}{c}\text { Activity } \\
\text { No. }\end{array}$ & $\begin{array}{c}\text { No. of measurement } \\
\text { analysis } \\
\text { (with wind/without wind) }\end{array}$ & \multicolumn{1}{|c|}{ Name of activity } & \multicolumn{1}{c|}{ Devices in motion } & $\begin{array}{c}\text { Length } \\
\text { of activity } \\
{[\mathrm{min}]}\end{array}$ \\
\hline 1 & A59/A69 & $\begin{array}{l}\text { Everyday hygiene, } \\
\text { taking a shower }\end{array}$ & $\begin{array}{l}\text { Shower, toilet flushing, washing } \\
\text { machine, fridge in the distance }\end{array}$ & 25 \\
\hline 2 & A44/A68 & Hobby & $\begin{array}{l}\text { Heating stove with a closed } \\
\text { combustion chamber in the } \\
\text { room, fridge in the distance }\end{array}$ & 110 \\
\hline 3 & A43/A24 & $\begin{array}{l}\text { Rest, menial home activ- } \\
\text { ities, reading press and } \\
\text { web sides surfing }\end{array}$ & $\begin{array}{l}\text { Fridge and heating stove in the } \\
\text { distance, computer }\end{array}$ & 120 \\
\hline 4 & A60/A20 & Watching TV & TV set, fridge in the distance & 75 \\
\hline 5 & A42/A82 & $\begin{array}{l}\text { Walk, collecting children } \\
\text { from school }\end{array}$ & Traffic noise & 90 \\
\hline 6 & A21/A22 & $\begin{array}{l}\text { Going to work by local } \\
\text { means of transport }\end{array}$ & Bus - combustion engine & 60 \\
\hline $6^{*}$ & A5/A25 & Going to work by car & Car - combustion engine & 60 \\
\hline 7 & Sleeping & $\begin{array}{l}\text { Fridge and heating stove in the } \\
\text { distance }\end{array}$ & 480 \\
\hline
\end{tabular}

Activities in Table 2 and Table 3 marked * in further calculations were considered alternatively. 
- on average $1.5 \mathrm{~m}$ over the floor. Weather conditions inside, during conducting noise measurement were: temperature: $18-23^{\circ} \mathrm{C}$, humidity: $65-82 \%$, pressure: 960-1010 hPa, Weather conditions during the noise measurements outside were various as they were carried out in different seasons: temperature $0-29^{\circ} \mathrm{C}$, humidity: 66-89\%, pressure: $960-1010 \mathrm{hPa}$. The measurements were made by our own meteo station with a valid calibration certificate for two ranges of wind speed outside the building. This enabled taking into consideration the influence of outside aerodynamics conditions depending on the wind speed in the measurements results. The presented results were defined as carried out during windy weather, they were registered during days when the wind speed outside exceeded $5 \mathrm{~m} / \mathrm{s}$.

The measurements inside the building where made in a detached house with a usable attic. The house was made of brick, plastered inside, with plastic double glass windows, and it was situated in a residential area. Around there are streets of low traffic. The central part of a house was an open living room with other rooms around it. The daily exposure of infrasound noise was estimated by calculating the level of equivalent level $L_{G e q, 24}$, expressed in Eq. (1). Calculation of an equivalent level of sound concerned all typical daily activities of a housewife. The time of all activities was described with the accuracy of five minutes.

$$
L_{G e q, 24}=10 \log \left[\frac{1}{\sum t_{i}} \sum_{n}^{1}\left(10^{0.1 L_{G e q, i}} t_{i}\right)\right] \text {, }
$$

where $\sum t_{i}$ is the time in minutes, for the whole day 1440 minutes, $n$ is the number of activity, $L_{G e q, i}$ is the measured level for a single activity, $t_{i}$ is the length of activity in minutes.

There was also calculated a non-professional exposure to infrasound noise for the person working outside place of living, estimating the equivalent level $L_{G e q, 16}$, expressed in Eq. (2).

$$
L_{G e q, 16}=10 \log \left[\frac{1}{\sum t_{i}} \sum_{n}^{1}\left(10^{0.1 L_{G e q, i}} t_{i}\right)\right]
$$

where $\sum t_{i}$ is the time in minutes, for 16 hours $=960$ minutes, $n$ is the number of activity, $L_{G e q, i}$ is the measured level for a single activity, $t_{i}$ is the length of activity in minutes.

Made assumptions and the results are shown in tables comparing them with audible thresholds in Table 1 . The schedule of daily activities of a housewife and the schedule of a person working outside home was estimated before starting the measurement. Also, average times of doing particular activities were estimated before. Those assumptions are presented in Table 2 and Table 3. Sharing activities by two people is typical for a family where one person works for a living.

\section{Results}

\subsection{Results during non-windy weather}

The results of measurements in a form of equivalent sound levels and $1 / 3$ octave analyses are presented in Table 4, in the form of genuine files of the analyser.

Table 4. Results registered during - wind free weather.

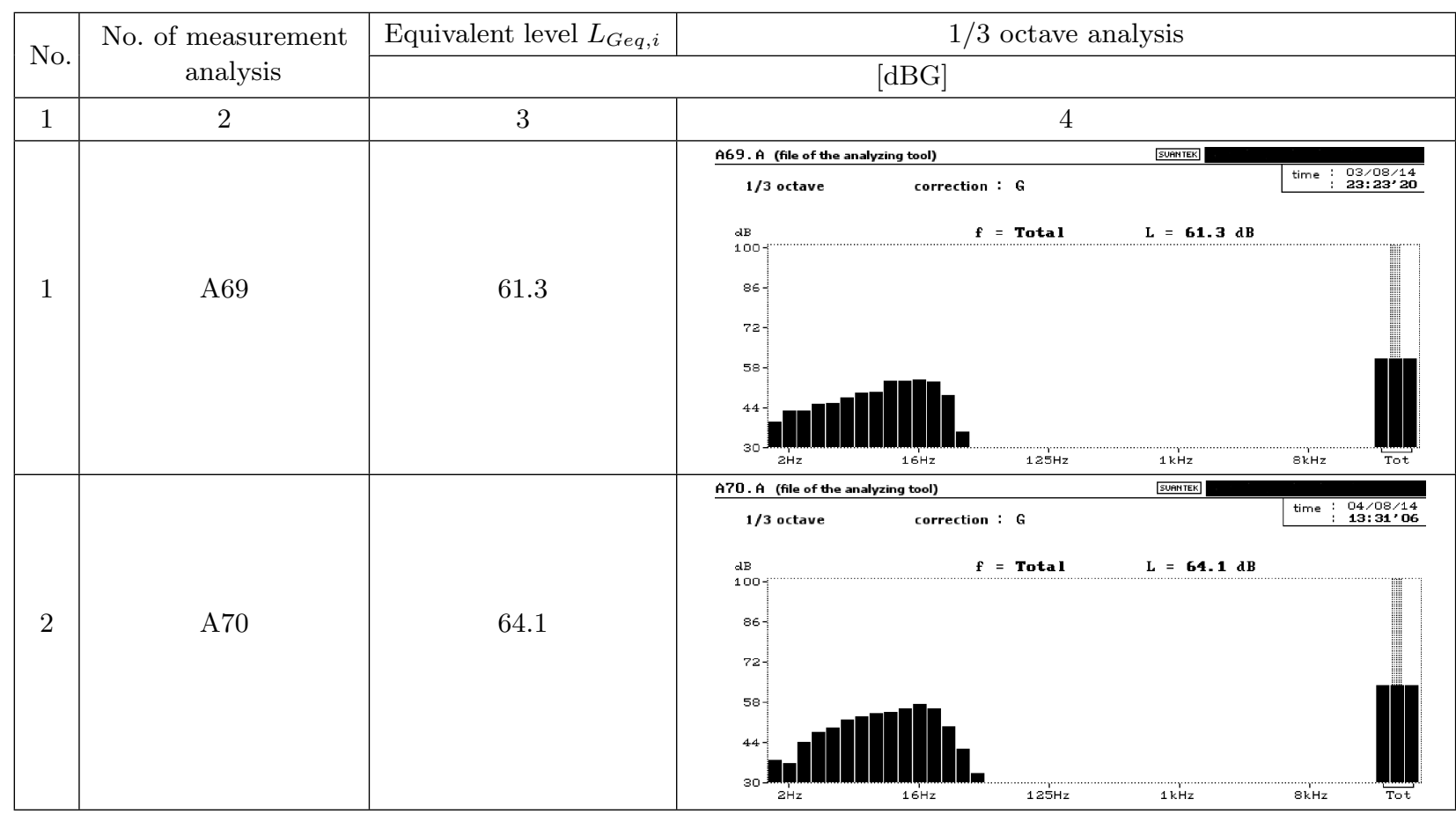


Table 4. [Cont.]

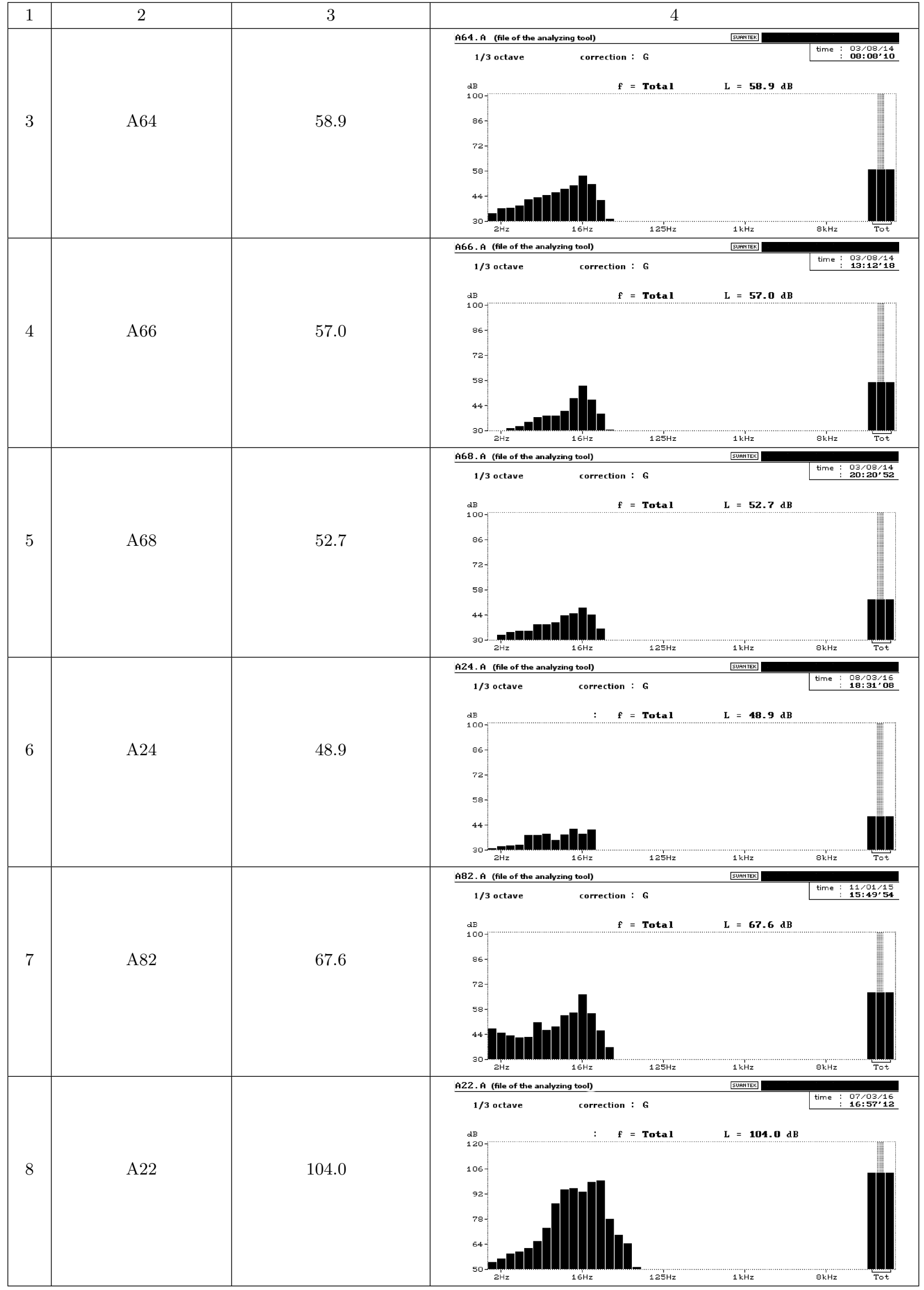


Table 4. [Cont.]

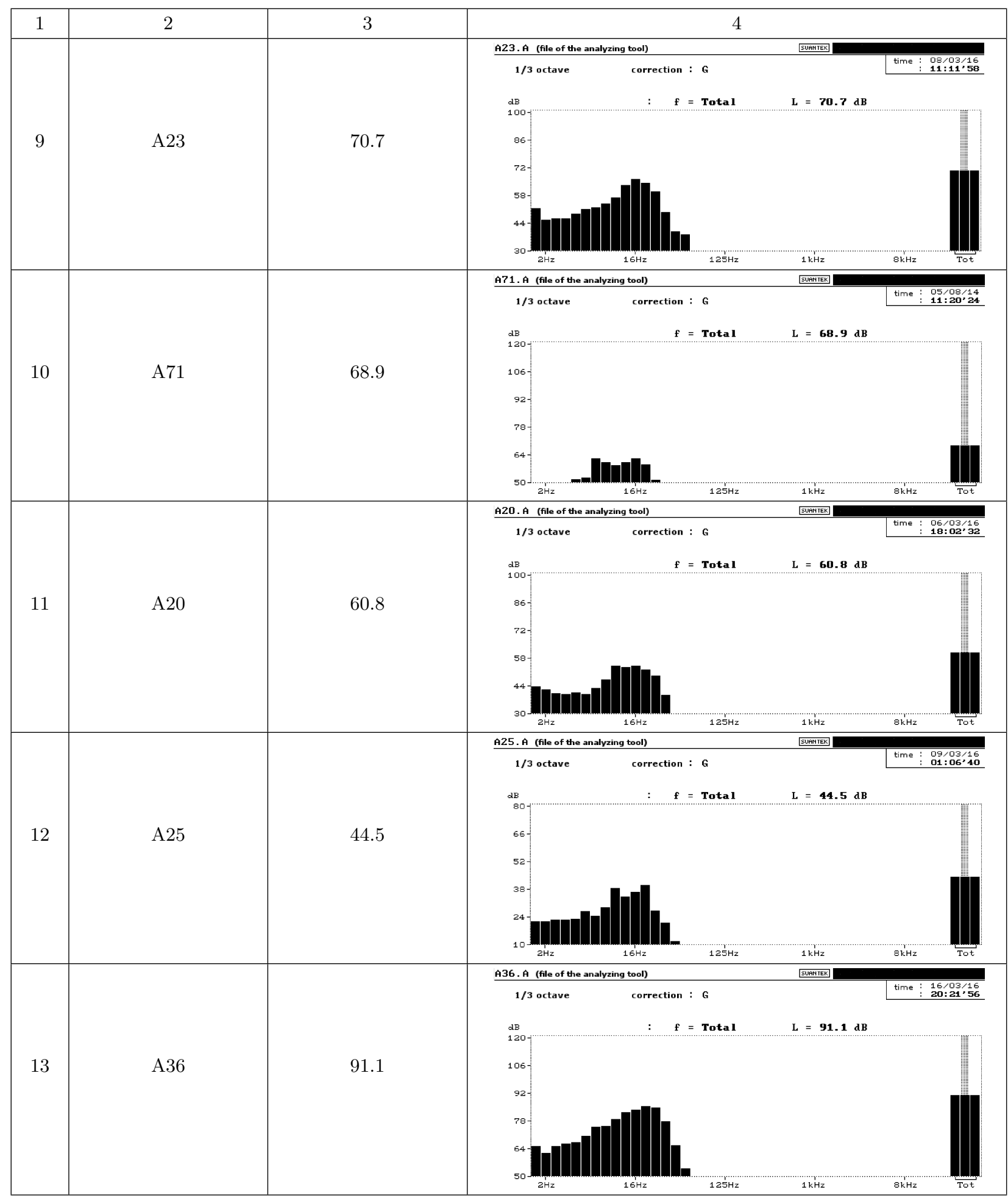

On the basis of the data included in Table 4 and schedules of home activities shown in Table 2 and Table 3, applying formulas (1) and (2) there was calculated a daily exposure to infrasound noise. The results of these calculations are shown in Table 5.
The results presented in Table 5 are shown alternatively for each person. Values marked with the asterisk $\left(^{*}\right)$ are calculated with taking into account drives by one's own car. The values without additional marking are for drives by a local bus. 
Table 5. Levels of exposure to infrasound noise during non-windy weather.

\begin{tabular}{|l|c|c|}
\hline \multirow{2}{*}{\multicolumn{1}{c|}{ Type of person }} & $\begin{array}{c}\text { Daily exposure } \\
\text { to infrasound noise } \\
L_{\text {Geq, }}\end{array}$ & $\begin{array}{c}\text { Non-occupational } \\
\text { exposure } \\
\text { to infrasound noise } \\
L_{\text {Geq, } 16}\end{array}$ \\
\cline { 2 - 3 } & \multicolumn{2}{|c|}{$[\mathrm{dBG}]$} \\
\hline Housewife & 90.2 & - \\
\hline Housewife & $77.3^{*}$ & 92.0 \\
\hline Person working outside home & - & $79.1^{*}$ \\
\hline Person working outside home & - & - \\
\hline
\end{tabular}

\subsection{Results during a windy weather}

The results of measurements in the form of equivalent levels and $1 / 3$ octave analysis are presented in Table 6 , in the form of genuine files of the analyser.

On the basis of the data included in Table 6 and home activities schedules shown in Table 2 and Table 3, applying formulas (1) and (2), a daily exposure to infrasound noise was calculated. The results of calculations are shown in Table 7.

Results presented in Table 7 are shown for each person alternatively.

The values marked with the asterisk $(*)$ are calculated with taking into account drives by one's own car and values without marking are for drives by the local bus.

Table 6. Results of measurements during windy weather.

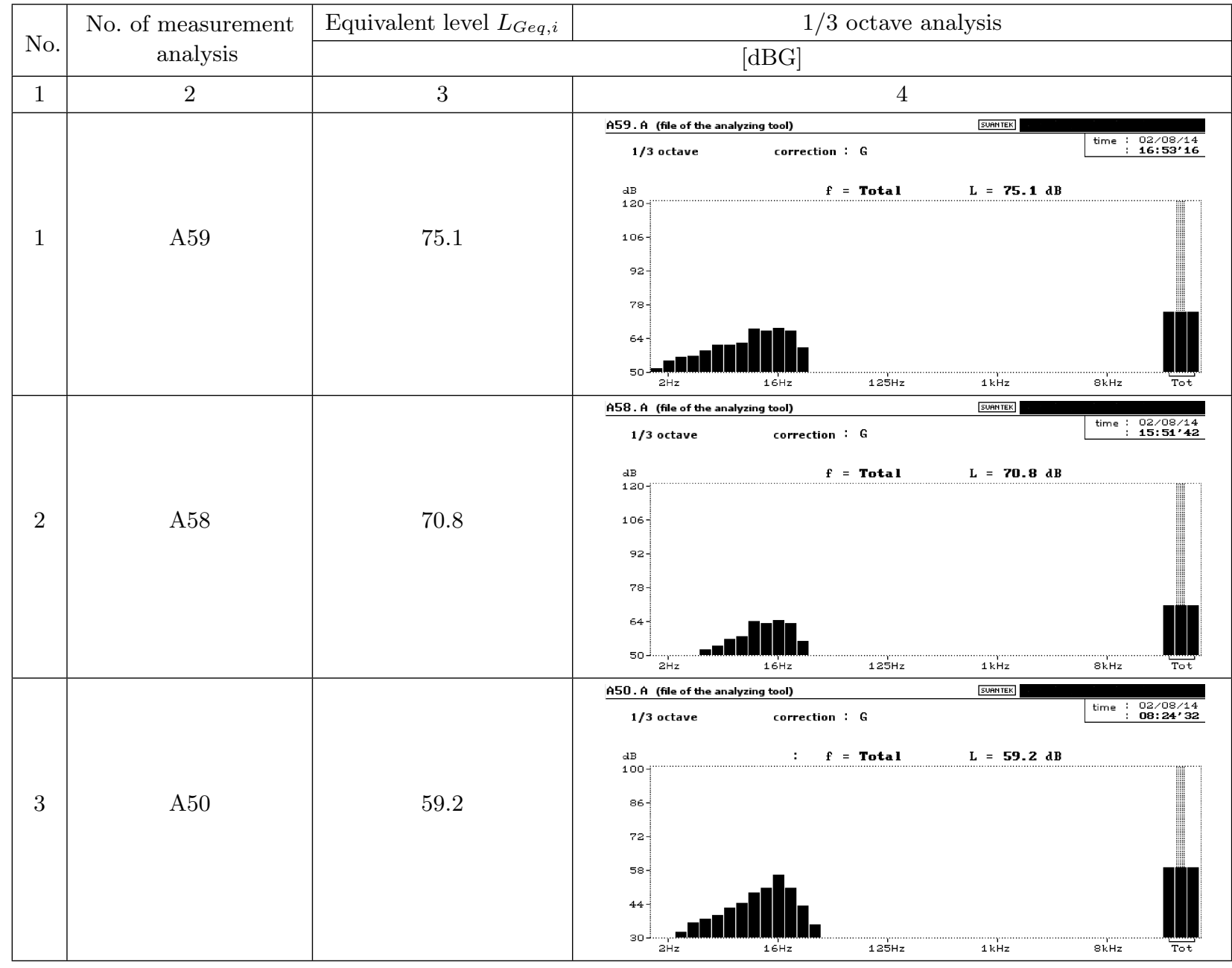


Table 6. [Cont.]

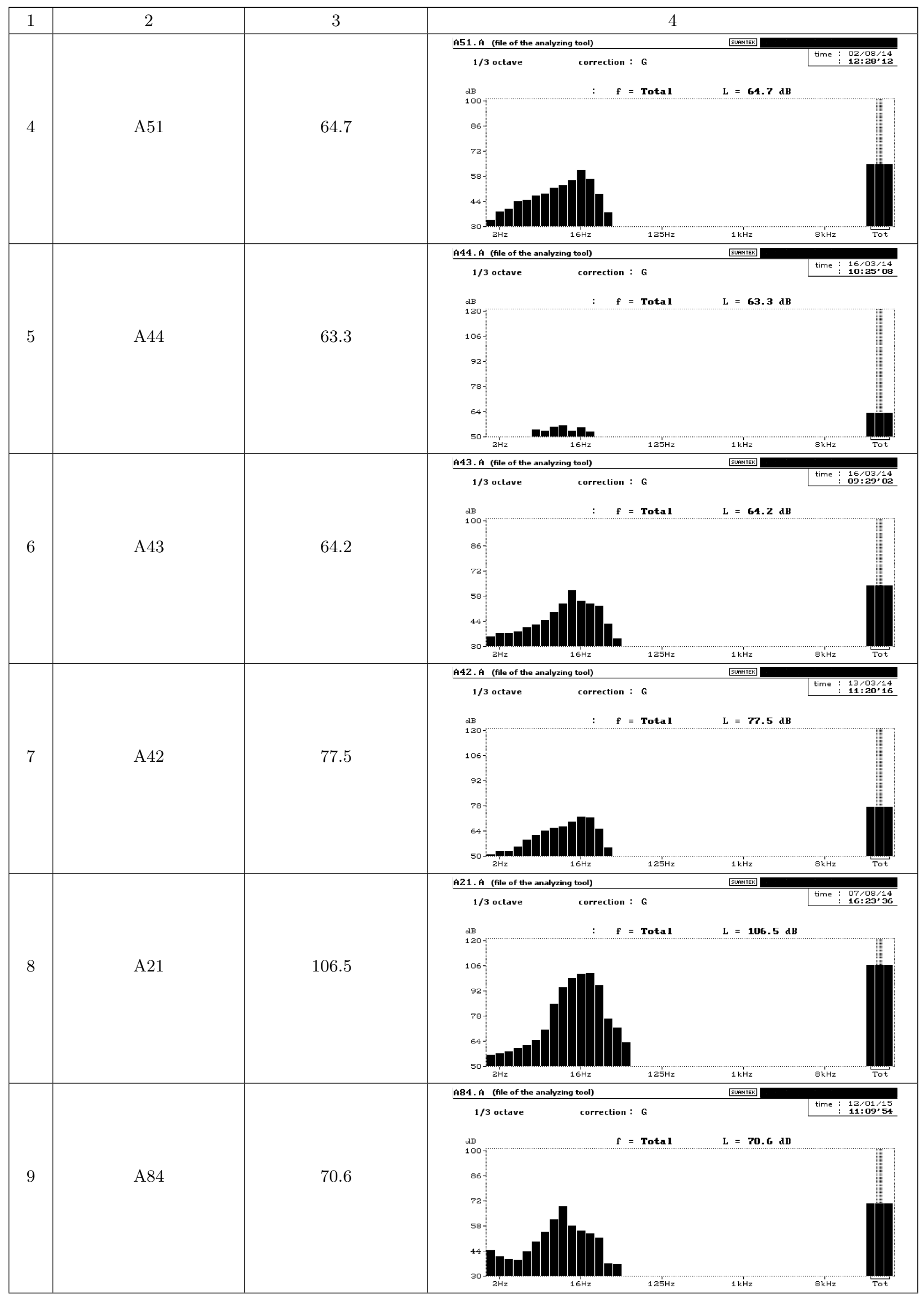


Table 6. [Cont.]

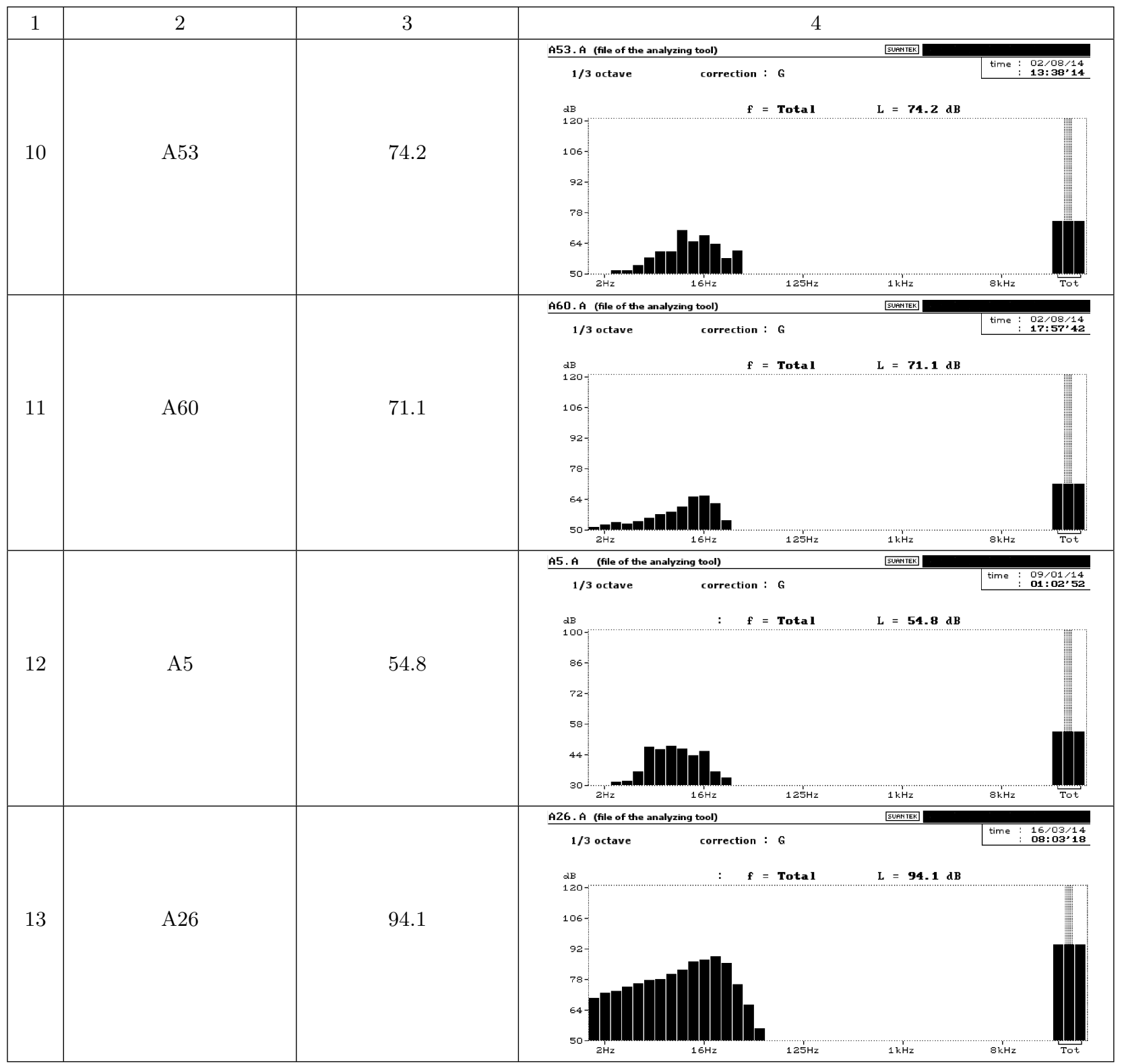

Table 7. Levels of exposure to infrasound noise during windy weather.

\begin{tabular}{|l|c|c|}
\hline \multirow{2}{*}{\begin{tabular}{c}
\multirow{2}{*}{ Type of person } \\
Housewife
\end{tabular}} & $\begin{array}{c}\text { Daily exposure } \\
\text { to infrasound noise } L_{G e q, 24}\end{array}$ & $\begin{array}{c}\text { Non-occupational exposure } \\
\text { to infrasound noise } \\
L_{G e q, 16}\end{array}$ \\
\cline { 2 - 3 } & \multicolumn{2}{|c|}{$[\mathrm{dBG}]$} \\
\hline \multirow{2}{*}{ Person working outside home } & 92.7 & - \\
\cline { 2 - 3 } & $80.7^{*}$ & 94.5 \\
\cline { 2 - 3 } & - & $82.3^{*}$ \\
\hline
\end{tabular}

\section{Discussion and conclusions}

The analysis of the carried out measurements and calculations allows us to draw the following conclusions:
1. Average values of audible threshold for particular frequencies of the $1 / 3$ octave analysis, shown in Table 1, were exceeded only during moving by means of transport. 
2. Only during drives by bus the level $102 \mathrm{dBG}$, suggested by the Polish norm (PN-Z-01338, 2010), as exposure for eight hour work, was exceeded. During the measurements the infrasound noise level was 104.0 and $106.5 \mathrm{dBG}$. These levels for a 60 minute exposure have a significant influence on the calculated levels of the daily exposure and non-professional exposure for both analysed people and they were shown in Table 5 and Table 7 . In the same time it must be noticed that the bus driver is exposed to 8-hour infrasound impact of levels higher than $102 \mathrm{dBG}$.

3 . The results of the conducted measurements in dwelling buildings do not exceed 85 dBG described in Denmark as permissible from outside sources (JACOBSEN, 2001).

4. The calculated levels of daily exposure for both people sharing one household were between 77.3 to $94.5 \mathrm{dBG}$.

5 . In the case of the person working outside home the results may be useful to estimate the daily exposure to the infrasound noise together with the occupational exposure.

6. It must be noticed that when doing a partial research of the infrasound influence on human health, especially during a long term exposure, it is difficult to estimate the right permissible levels. The knowledge of the non-occupational exposure to the infrasound may help to estimate reasonable permissible values.

7. The measurements' results are highly comparable with the calculations presented in the wide measurement report (LUBW, 2016).

\section{References}

1. Berglund B., Hassemen P. (1996), Sources and effects of low-frequency noise, Journal of the Acoustical Society of America, 99, 2985-3002.
2. ISO 7196 Acoustics (1995), Frequency weighting characteristic for infrasound measurements.

3. JaCoBsen J. (2001), Danish guidelines on environmental low frequency noise, infrasound and vibration, Journal of Low Frequency Noise, Vibration and Active Control, 20, 3, 141-148.

4. Leventhall G., Pelmear P., Benton S. (2003), A review of Published Research on Low Frequency Noise and Its Effects, Defra Publications, London.

5. LUBW - Landesanstalt für Umwelt, Messungen und Naturschutz Baden-Württemberg (2016), Noise of low frequency including infrasound coming from wind turbines and other sources [in German], BadenWürttemberg, Germany.

6. Møller H., Pedersen CS. (2004), Hearing at low and infrasonic frequencies, Noise and Health, 6, 23, $37-57$.

7. Pawlaczyk-Łuszczyńska M. (1999), Evaluation of occupational exposure to infrasonic noise in Poland, International Journal of Occupational Medicine and Environmental Health, 12, 2, 159-176.

8. Pawlas K., Pawlas N., Boroń M., SzŁapa P., ZACHARA J. (2013), Infrasound and low frequency noise assessment at workplaces and environment - review of criteria [in Polish], Environmental Medicine, 16, 1, 82-89.

9. Piecuch I., Piecuch T. (2011), Teaching About the Environment - It Is Never too Early and It Is Never too Late [in Polish], Annual Set The Environment Protection, 13, 711-722.

10. PN-Z 01338 Acoustics (2010), Measurement and assessment of infrasonic noise at work stations [in Polish], Copyright by PKN, Warszawa.

11. VAN DER BERG M. (2005), Influence of low frequency noise on health and well-being, UK: Informal Draft No GBR-41-8, www.unece.org.

12. Watanabe T., Møller H. (1990), Low frequency hearing threshold in pressure and in free field, Journal of Low Frequency Noise and Vibration, 9, 3, 106-115. 